1992

\title{
Effect of Operating Conditions on Gearbox Noise
}

Fred B. Oswald

NASA Lewis Research Center

James J. Zakrajsek

NASA Lewis Research Center

Dennis P. Townsend

NASA Lewis Research Center

William Atherton

Cleveland State University, w.atherton@csuohio.edu

Hsiang Hsi Lin

Memphis State University

Follow this and additional works at: https://engagedscholarship.csuohio.edu/enme_facpub

Part of the Acoustics, Dynamics, and Controls Commons

How does access to this work benefit you? Let us know!

\section{Recommended Citation}

Oswald, Fred B.; Zakrajsek, James J.; Townsend, Dennis P.; Atherton, William; and Lin, Hsiang Hsi, "Effect of Operating Conditions on Gearbox Noise" (1992). Mechanical Engineering Faculty Publications. 6.

https://engagedscholarship.csuohio.edu/enme_facpub/6

This Report is brought to you for free and open access by the Mechanical Engineering Department at EngagedScholarship@CSU. It has been accepted for inclusion in Mechanical Engineering Faculty Publications by an authorized administrator of EngagedScholarship@CSU. For more information, please contact library.es@csuohio.edu. 


\section{Effect of Operating Conditions on Gearbox Noise}

Fred B. Oswald, James J. Zakrajsek, and Dennis P. Townsend Lewis Research Center Cleveland, Ohio

William Atherton

Cleveland State University

Cleveland, Ohio

and

Hsiang Hsi Lin

Memphis State University

Memphis, Tennessee

Prepared for the

Sixth International Power Transmission and Gearing Conference sponsored by the American Society of Mechanical Engineers Phoenix, Arizona, September 13-16, 1992 


\title{
EFFECT OF OPERATING CONDITIONS ON GEARBOX NOISE
}

\author{
Fred B. Oswald, James J. Zakrajsek, and Dennis P. Townsend \\ National Aeronautics and Space Administration \\ Lewis Research Center \\ Cleveland, Ohio 44135 \\ William Atherton \\ Cleveland State University \\ Cleveland, Ohio 44115 \\ and \\ Hsiang Hsi Lin \\ Memphis State University \\ Memphis, Tennessee 38152
}

\section{ABSTRACT}

Low-contact-ratio spur gears were tested in the NASA gearnoise rig to study the noise radiated from the top of the gearbox. The measured sound power from the gearbox top was obtained from a near-field acoustic intensity scan taken at 63 nodes just above the surface. The sound power was measured at a matrix of 45 operating speeds and torque levels. Results are presented in the form of a spectral speed map and as plots of sound power versus torque (at constant speed) and as sound power versus speed (at constant torque). Because of the presence of vibration modes, operating speed was found to have more impact on noise generation than torque level.

A NASA gear dynamics code was used to compute the gear tooth dynamic overload at the same 45 operating conditions used for the experiment. Similar trends were found between the analytical results for dynamic tooth overload and experimental results for sound power. Dynamic analysis may be used to design high-quality gears with profile relief optimized for minimum dynamic load and noise.

\section{INTRODUCTION}

A major source of helicopter cabin noise (which has been measured at over $100 \mathrm{~dB}$ sound pressure level) is the gearbox. Reduction of this noise is a NASA and U.S. Army goal. Gearmesh noise is typically in the frequency range of 1000 to $3000 \mathrm{~Hz}$, a range important for speech. A requirement for the U.S. Army/NASA Advanced Rotorcraft Transmission project is a $10-\mathrm{dB}$ noise reduction compared to current designs. A combined analytical/experimental effort is underway to study effects of design parameters on noise production.

The information in the literature relating gearbox noise to operating conditions such as speed and torque is not consistent. Much of the confusion may be the result of (1) differing levels of accuracy of the gears used by the various researchers, (2) variation in structural effects (mechanical resonance), and (3) differences in the radiation efficiencies of different structures.

Houser (1991) suggests that a perfect gearbox may radiate $10^{-9}$ of its input power as noise. For a very high-quality gearbox, this ratio is on the order of $10^{-7}$ to $10^{-8}$. If the noise represents a constant fraction of power, doubling either speed or torque would produce a $3-\mathrm{dB}$ noise increase. Houser cites references reporting a noise level increase from 2 or $3 \mathrm{~dB}$ to $10 \mathrm{~dB}$ for doubling of speed. Likewise, doubling gearbox torque has produced reported noise level increases from 3 to $6 \mathrm{~dB}$.

A simplified equation presented in an appendix to Bossler et al. (1978) predicts that, for spur gears, the sound power level in decibels at the meshing frequency will vary by a factor of $20 \operatorname{LOG}(\tau)+37.8 \mathrm{LOG}(\mathrm{f})$ where $\tau$ is the transmitted torque and $\mathrm{f}$ is the gearmesh frequency in $\mathrm{Hz}$. This indicates that the sound power will increase by $6 \mathrm{~dB}$ as the torque doubles and by $11 \mathrm{~dB}$ as the speed doubles.

Levine and DeFelice (1977) report sound power increases of $1.2 \mathrm{~dB}$ for bevel gears and 3 to $4 \mathrm{~dB}$ for planetary gears for a doubling of horsepower. Shahan and Kamperman (1966) contains figures relating sound pressure level to specific tooth load and to rotation speed. They show an approximate $2.5-\mathrm{dB}$ sound pressure level (SPL) increase for a doubling of specific tooth load and a similar 2.5-dB SPL increase for doubling of speed for gears with a profile error of $0.0002 \mathrm{in}$. (This tolerance translates to AGMA class 13 for small gears such as those tested in the present work.) Watanabe and Rouverol (1990) plot noise level as a function of speed for various automotive timing gears. Their curves typically show a 10- $\mathrm{dB}$ increase for a doubling of speed. Atherton et al. (1987) present a plot showing sound power at mesh frequency which shows little torque effect. Finally, Houser (1991) mentions that some researchers report a noise level decrease as torque is increased.

Various analytical codes are available to simulate gear dynamics, vibration, and noise. These include DANST (dynamic analysis of spurgear transmissions) (Lin et al., 1987a, 1987b, and 1989), GEARDYN (gear dynamics) (Boyd and Pike, 1987 and Pike, 1981); and GRD (geared rotor dynamics) (Kahraman et al., 1990). Finite element methods may also be used to predict the structural vibration properties of a gearbox. The boundary element method for acoustic prediction (BEMAP) may be used to predict the noise from vibration data (Seybert et al. 1991). 
Part of NASA gear noise research is directed toward validating computer codes so that the codes may be used as design tools. Earlier work in this project produced dynamic load and stress data for validation of the NASA gear dynamics code DANST (Oswald et al. 1991). A related project provided validation data for the acoustics code BEMAP (Oswald et al., 1992).

The goal of this effort has been to provide experimental data to assess the effects of speed and torque on the noise produced by a gearbox. Results presented include narrow-band spectra of the sound power and trends of mesh frequency sound power as speed and torque are varied. This paper compares the trends of dynamic overload as predicted by the DANST code with measured gearbox noise.

\section{APPARATUS}

$\underline{\text { Test Facility }}$

The NASA Lewis gear-noise rig (Fig. 1) was used for these tests. This rig features a single-mesh gearbox powered by a $150-\mathrm{kW}$

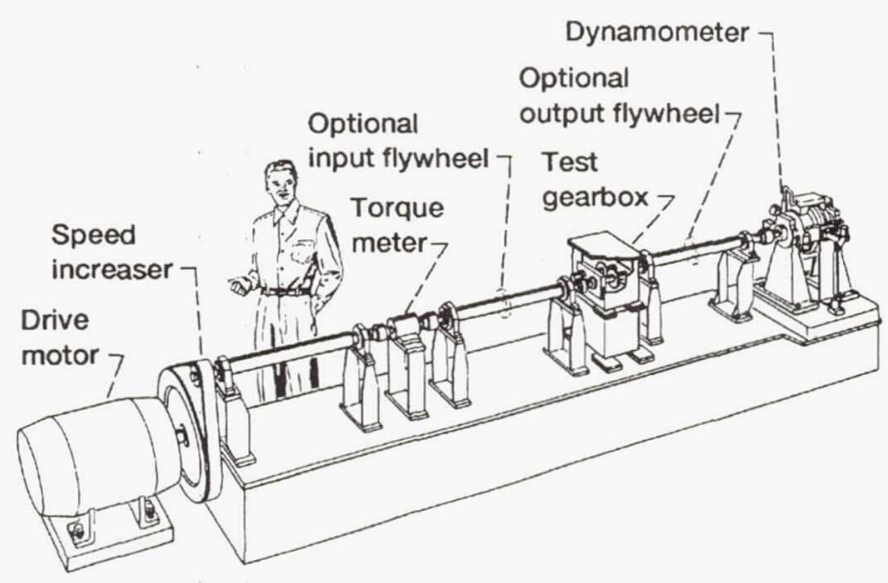

(a) Layout.

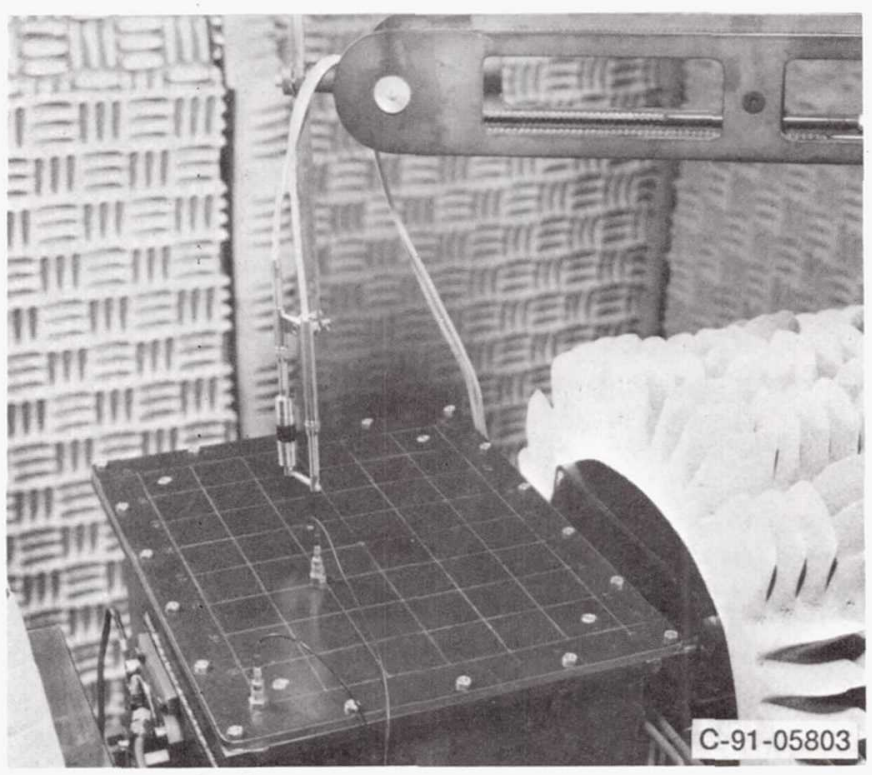

(b) Test gearbox showing measurement grid and RAIMS robot with sound intensity probe.

Figure 1.-NASA gear-noise rig. (200-hp) variable-speed electric motor. An eddy-current dynamometer loads the output shaft. The gearbox can be operated at speeds up to $6000 \mathrm{rpm}$. The rig was built to carry out fundamental studies of gear noise and the dynamic behavior of gear systems. It is designed to allow testing of various configurations of gears, bearings, dampers, and supports. To reduce unwanted reflection of noise, acousticabsorbing foam baffles covered the test cell walls, floor, and other nonmoving surfaces. The material used attenuates the reflected sound by $20 \mathrm{~dB}$ for frequencies of $500 \mathrm{~Hz}$ and above.

A poly-V belt drive was used as a speed increaser between the motor and input shaft. A soft coupling was installed on the input shaft to reduce input torque fluctuations, which were caused by nonuniformity at the belt splice.

The test gears were identical spur gears (at 1:1 ratio) machined to AGMA Class 15 accuracy. The gear profiles were modified with linear tip relief chosen for optimum operation at design load. Test gear parameters are shown in Table I.

\section{TABLE I.-TEST GEAR PARAMETERS}

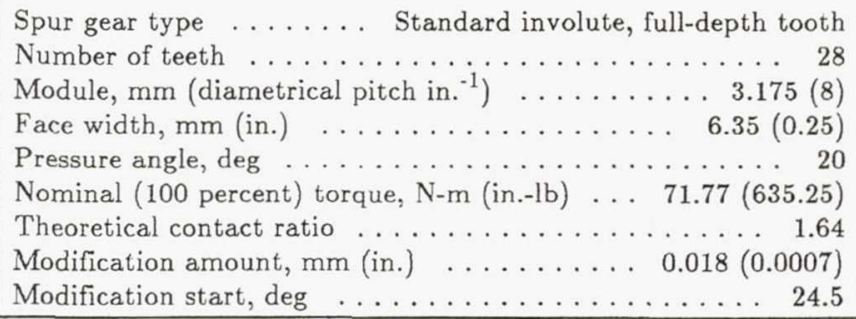

A 63-node measurement grid was marked out on the top of the gearbox. The grid covers an area 228 by $304 \mathrm{~mm}$ ( 9 by 12 in.) centered on the 286 - by $362-\mathrm{mm}$ (11.25- by 14.25 -in.) top. The gearbox with its measurement grid and some instrumentation are shown in Fig. 1(b).

\section{Instrumentation and Test Procedure}

An experimental modal test was performed to determine the modes of vibration and natural frequencies of the gearbox top. An 800-line, 2-channel dynamic signal (FFT) analyzer collected frequencydomain data. Commercial modal software running on a personal computer was used for the analysis. The modal tests were performed with the top installed on the gearbox and with the gearbox heated to operating temperature. The structure was excited sequentially at each of the 63 nodes using a load-cell-equipped modal hammer to measure excitation forces. The response was measured with a small piezoelectric accelerometer mounted at a reference location near the center of the gearbox top.

Acoustic intensity measurements were performed under stable, steady-state operating conditions with the aid of a computer-controlled robot designated RAIMS (robotic acoustic intensity measurement system). The RAIMS software (1) commanded the robot to move an intensity probe over a prescribed measurement grid; (2) recorded acoustic intensity spectra in the analyzer for each node of the grid; and (3) transmitted the spectra to the computer for storage on disk. RAIMS is more completely described in Flanagan and Atherton (1985) and in Atherton et al. (1987).

The acoustic intensity probe consists of a pair of phasematched $12-\mathrm{mm}$ microphones mounted face-to-face with a $12-\mathrm{mm}$ spacer. The probe has a frequency range of 125 to $5000 \mathrm{~Hz}( \pm 1 \mathrm{~dB})$. Measurements were made at a distance of $75 \mathrm{~mm}$ between the acoustic center of the microphones and the gearbox top. 
The 63 intensity spectra collected at each operating condition were averaged, then multiplied by the radiation area to compute an 800 -line sound power spectrum. The radiation area was assumed to be the area of the grid plus one additional row and column of elements or $0.0910 \mathrm{~m}^{2}$. The actual area of the top is $0.1034 \mathrm{~m}^{2}$. The measurement grid did not extend completely to the edges of the gearbox top because (1) the edge of the top was bolted to a stiff mounting flange which would not allow much movement, and (2) measurements taken close to the edge of the top would be affected by noise radiated from the sides of the box. Noise measurements from the gearbox sides were not attempted for the following reasons:

(1) the top is not as stiff as the sides; thus, noise radiation from the top dominates; (2) the number of measurement locations were kept reasonable; and (3) shafting and other projections made such measurements difficult.

Sound power measurements were made at a matrix of 45 test conditions: 5 speeds $(2000,3000,4000,5000$, and $6000 \mathrm{rpm})$ and 9 torque levels $(16,31,47,63,79,94,110,126$, and 142 percent of the reference torque $71.8 \mathrm{~N}-\mathrm{m}(635 \mathrm{in}-\mathrm{lb}))$. During measurements, speed was held to within $\pm 4 \mathrm{rpm}$ and torque to $\pm 1 \mathrm{~N}-\mathrm{m}$. Acoustic data was recorded over the bandwidth 0 to $3200 \mathrm{~Hz}$.

\section{ANALYTIC MODEL}

Computer program DANST employs four torsional degrees of freedom. These degrees of freedom represent the input (motor), the two gears, and the output (load) (Lin, 1987a, 1987b, 1989, and Oswald et al., 1991). Equivalent mass and stiffness elements were estimated to represent the input (motor) and output (dynamometer) elements of the gear-noise rig. The gear tooth profiles were modeled as perfect involutes from the low point of tooth contact to the start of modification; the tooth tips are modified with linear tip relief as specified in Table I. DANST provided a dynamic solution for gear tooth loads.

\section{RESULTS AND DISCUSSION}

Plots of the first four vibration modes found from modal tests are shown in Fig. 2. (These modes occur at slightly different frequencies than those reported in Seybert et al. (1991). The difference is due to different clamping conditions for the top. A soft cork gasket under the gearbox top has been replaced by a rubber O-ring in a machined groove. The O-ring allows stiffer clamping.)

A spectral map compares sound power for the 5 different speeds at the constant torque level of 94 percent in Fig. 3. The gearmesh frequency is indicated on each curve. Three pairs of sidebands around the mesh frequency are indicated (only on the top trace). The first five modes from the modal tests are identified at the top of the figure. On the 2000-rpm curve, the gearmesh frequency $(933 \mathrm{~Hz}$ ) is very close to mode $\mathrm{B}$ at $975 \mathrm{~Hz}$. Likewise, the $2333-\mathrm{Hz}$ gearmesh frequency on the $5000-\mathrm{rpm}$ curve is near the $2296-\mathrm{Hz}$ mode $\mathrm{E}$.

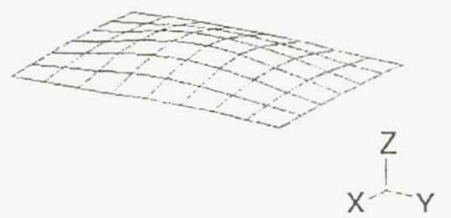

(a) $1 / 1$ mode, $511 \mathrm{~Hz}$.

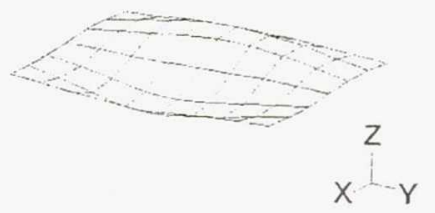

(c) $1 / 2$ mode, $1273 \mathrm{~Hz}$.

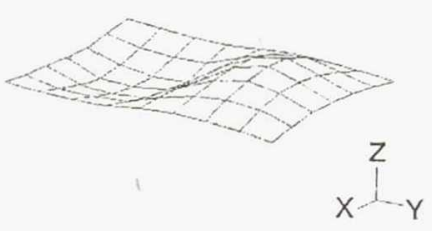

(b) $2 / 1$ mode, $975 \mathrm{~Hz}$.

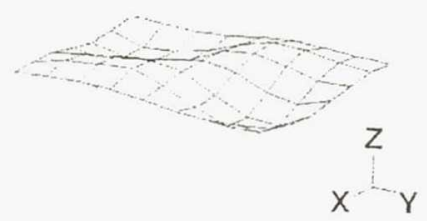

(d) $2 / 2$ mode, $1631 \mathrm{~Hz}$.

Figure 2.-Gearbox vibration modes.

\section{A, B, C, D, E Vibration modes $M \quad$ Gear mesh frequency S Sideband frequency}

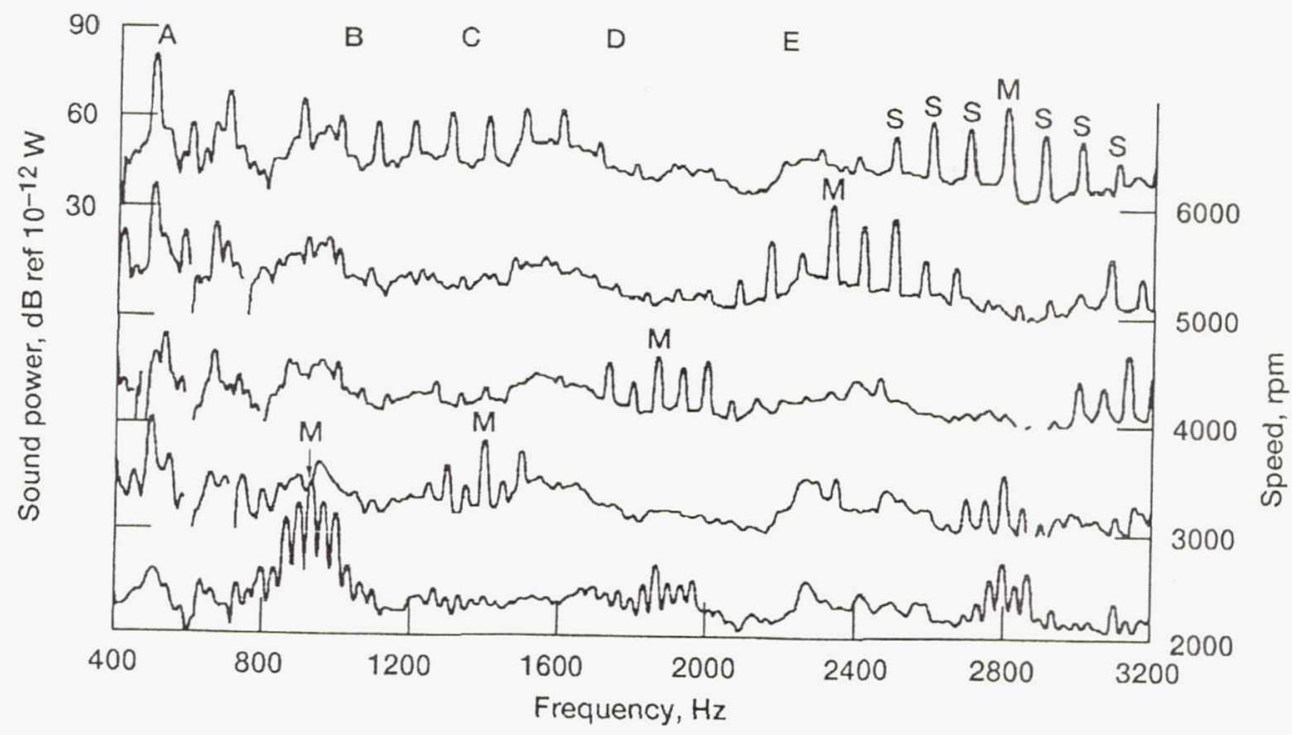

Figure 3.-Sound power measurements at 5 speeds (constant 94-percent torque level). 
The measured sound power includes some noise originating the from the motor, shafting, or other noise sources refracted or reflected to the measurement location. Most of this noise from sources other than the gearbox occurs at low frequencies (below about $400 \mathrm{~Hz}$ ). Low-frequency noise is expected to contaminate the measurements because the acoustic baffles decline in absorption ability at low frequencies and because low-frequency noise is more likely to be refracted to the intensity probe. Because of this low-frequency noise, frequencies below $400 \mathrm{~Hz}$ are not shown in the spectra of Fig. 3. Even somewhat above $400 \mathrm{~Hz}$, there were a few frequency bands in which the sound intensity flow direction was toward the gearbox; hence, the intensity was negative. These frequencies show up as gaps in the sound power curves.

The data used in the spectra in Fig. 3 and similar data from the other eight torque levels tested were used to compute the mesh sound power. The mesh sound power is defined here as the sum of the sound power at gearmesh frequency and at three pairs of sidebands (i.e., the sum of seven values). These data are shown for 45 test conditions ( 5 speeds and 9 torques) in Figs. 4 and 5.

Figure 4 presents mesh sound power as a function of speed at the nine torque levels. The highest noise levels are found at 5000 and $2000 \mathrm{rpm}$. The noise levels at $5000 \mathrm{rpm}$ are highest at low torque, whereas the 2000-rpm levels are greatest at high torque. The expected trend of generally rising noise level with speed has been overwhelmed by modal response in Fig. 3. The highest noise levels are produced by operation at speeds (2000 and $5000 \mathrm{rpm}$ ) which excite vibration modes. It is difficult to find a general trend in this data for the effect of speed on gearbox noise caused by the presence of vibration modes.
Figure 5 presents mesh sound power as a function of torque at five speed levels. Each curve shows a minimum-noise torque level. This minimum-noise level appears to be speed-dependent: At the lowest speeds (2000 and $3000 \mathrm{rpm}$ ), minimum noise occurs at approximately 50-percent torque. At the higher speeds (especially 5000 and $6000 \mathrm{rpm}$ ), the minimum noise occurs near 100-percent torque.

Operation at torque much above or below the optimum level produces much higher noise. Especially notable is the 5000-rpm curve in which the noise at 16-percent torque is $22 \mathrm{~dB}$ greater than that at 110-percent torque. High-speed, low-torque operation may produce gear rattle where the gear teeth momentarily lose contact, then collide. These tooth collisions produce high overloads. Gear dynamic response at light load is discussed in Rebbechi et al. (1992).

In the results presented in Fig. 5, no general trend of gearbox noise rising with increasing torque can be found although the torque was varied by a factor of 7 to 1 . Indeed, certain torque levels seem to produce minimum noise. Houser (1991) discusses designing gears for minimum transmission error (and hence minimum noise). Figure 5 suggests that the profile modifications, which were chosen from an analysis using DANST, are nearly optimum for 100-percent load. At low-torque operation the profile modification is excessive and noise is high.

Since the DANST gear dynamics code cannot account for the modal properties of the gearbox, it is not meaningful to compare the trend of gearbox noise to DANST predictions as speed is varied. However, torque variation, which affects the meshing action of the gears, is considered by DANST. Figure 6 shows the result of using DANST to simulate the 45 operating conditions for the experimental data in Fig. 3. The figure shows the dynamic overload (defined as

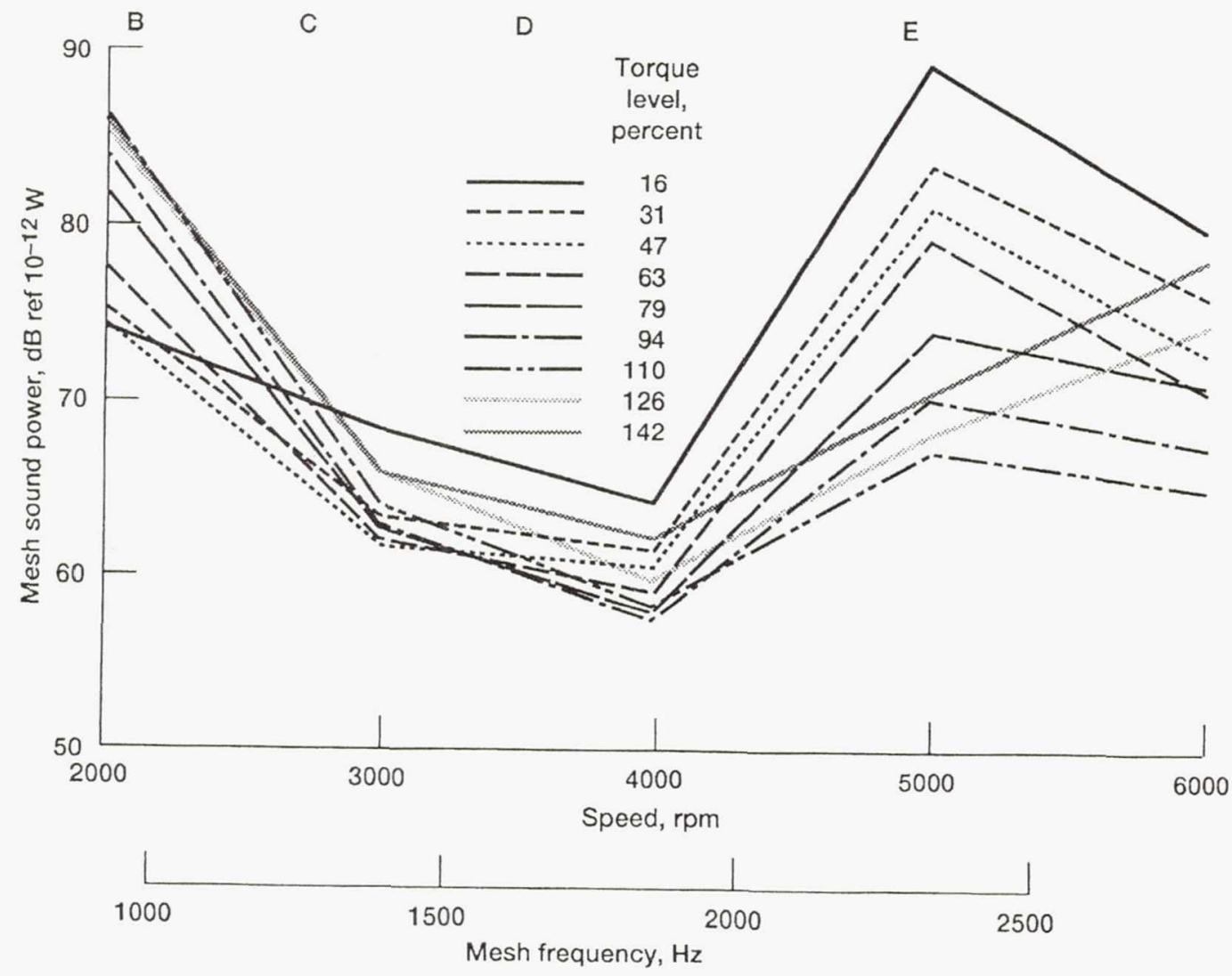

Figure 4.-Mesh sound power as a function of speed at 9 torque levels computed from the sum of values at mesh and at 3 pairs of sideband frequencies. 


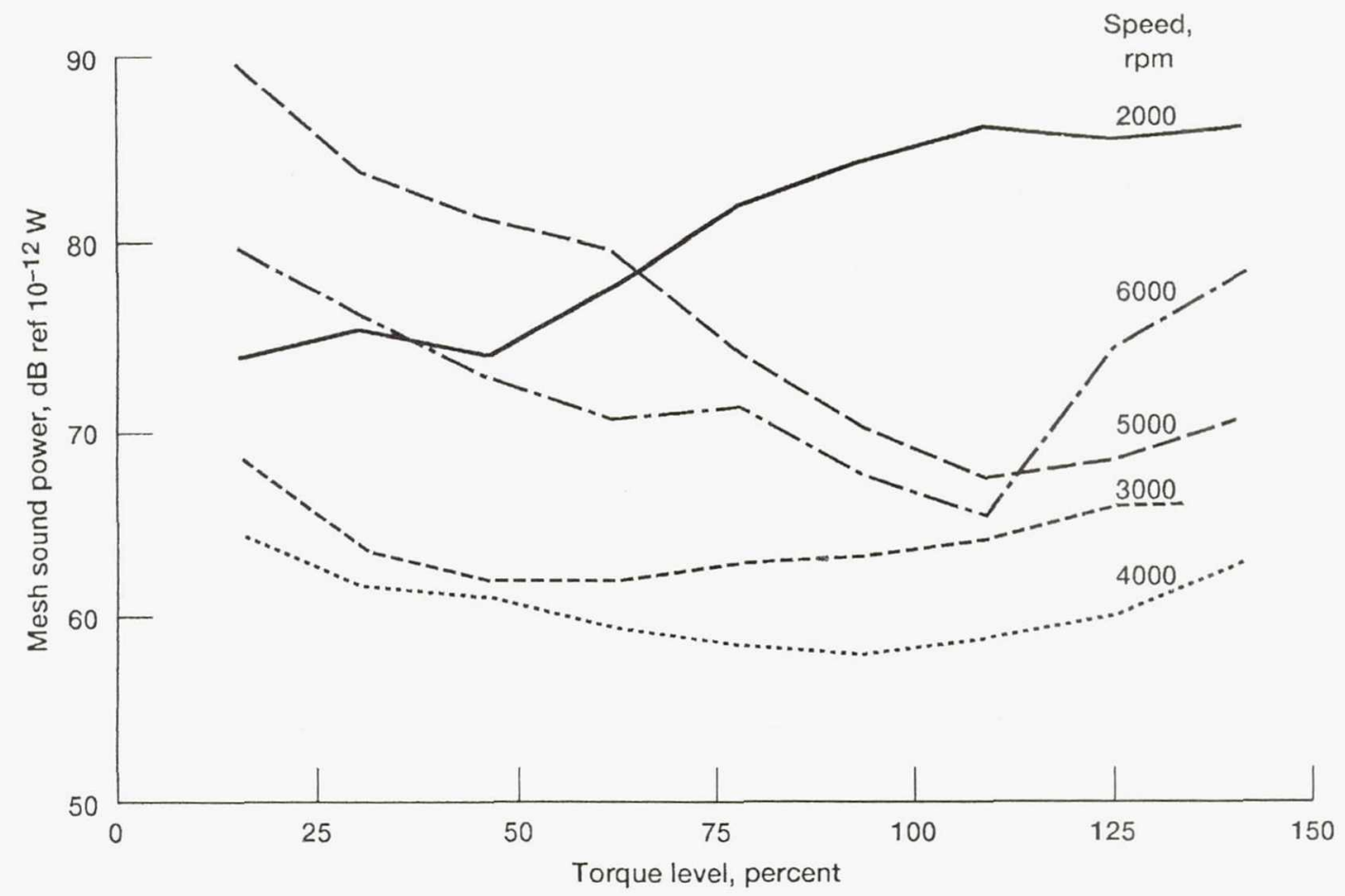

Figure 5.-Mesh sound power as a function of torque at 5 speeds computed from the sum of values at mesh and at 3 pairs of sideband frequencies.

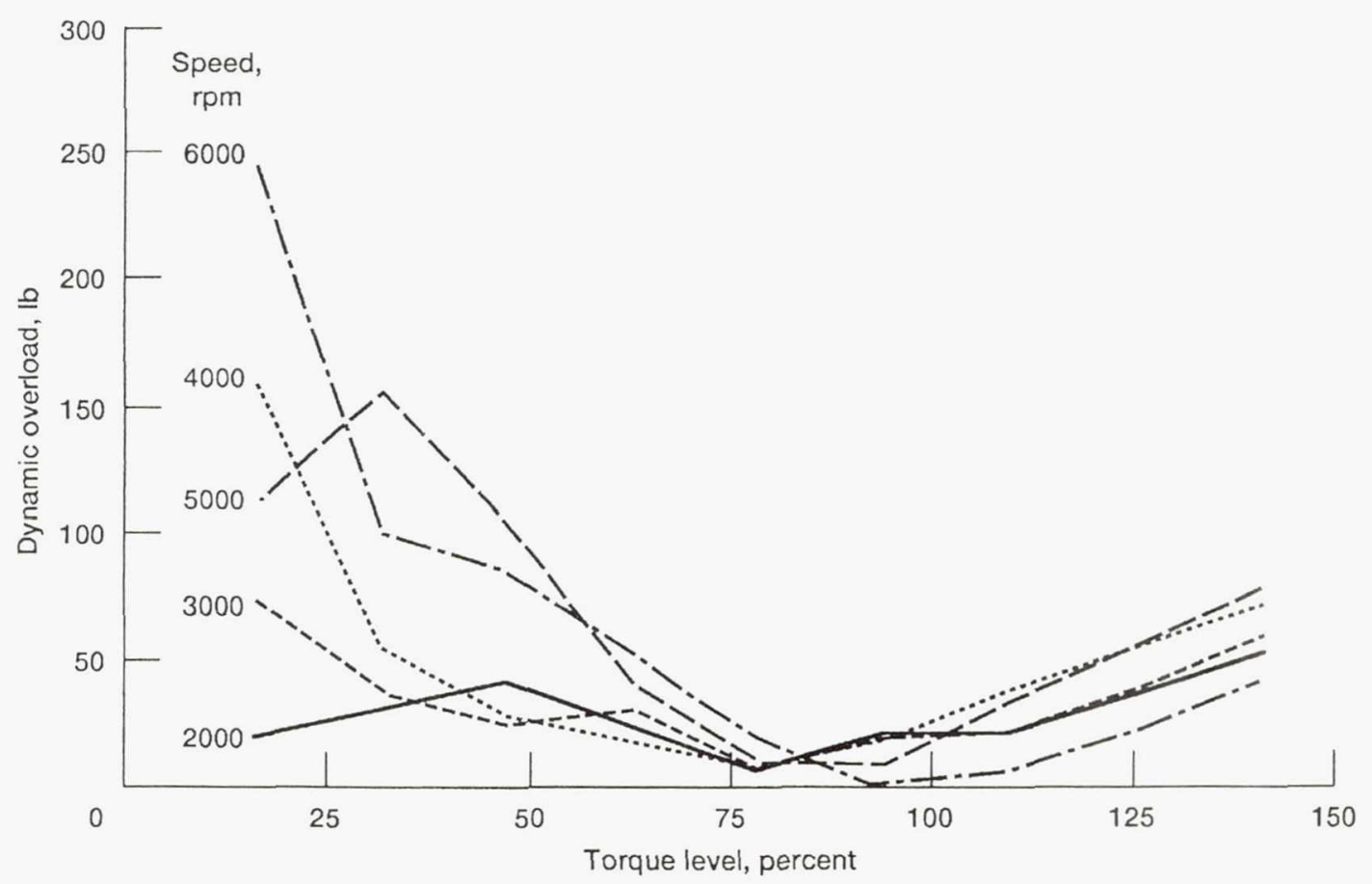

Figure 6.-Gear tooth dynamic overload predicted by DANST. Dynamic overload is computed from the difference between maximum tooth load and static tooth load. 
the maximum dynamic load minus the maximum static load) as a function of torque at five speeds. All curves show a minimum at 79- or 94-percent torque. Except for the 2000- and 3000-rpm curves, the minimum overload occurs at a torque level similar to that for minimum sound power in Fig. 5.

\section{CONCLUSIONS}

Measurements of gearbox noise were made in the NASA gearnoise rig to investigate the effect of operating conditions (speed and torque) on gearbox noise. Results were also compared to predictions of the gear dynamics code DANST. The following conclusions were obtained.

1. Similar trends were found between analytical results for dynamic tooth overload and experimental results for sound power. This indicates the dynamic analysis simulates the noise excitation of the gears.

2. Operating speed impacts gearbox noise generation more than torque, chiefly because of the presence of vibration modes. Operation at speeds which excite modes may produce very high noise levels.

3. High-quality spur gears, with proper profile relief, operate with minimum noise at the torque level which produces minimum dynamic response. Very low-torque operation may produce high dynamic loads and, therefore, high noise levels because of gear rattle.

4. The dynamic tooth loads and noise of high-quality spur gears may be minimized by proper choice of profile modification. This modification may be chosen using an analytical model of the gear pair.

\section{REFERENCES}

Atherton, W.J., Pintz, A., and Lewicki, D.G., 1987, "Automated Acoustic Intensity Measurements and the Effect of Gear Tooth Profile on Noise," Mechanical Signature Analysis-Machinery Vibration, Flow-Induced Vibration, and Acoustic Noise Analysis, S. Braun, et al., eds., ASME, pp. 109-113 (also, NASA TM-100155).

Bossler, R.B., Bowes, M.A., and Royal, A.C., 1978, "An Analytical Method for Designing Low Noise Helicopter Transmissions," Helicopter Acoustics, NASA CP-2052, Part 2, pp. 657-677.
Boyd, L.S., and Pike, J.A., 1987, "Expansion of Epicyclic Gear Dynamic Analysis Program," NASA CR-179563.

Flanagan, P.M., and Atherton, W.J., 1985, "Investigation on Experimental Techniques to Detect, Locate and Quantify Gear Noise in Helicopter Transmissions," NASA CR-3847.

Houser, D., 1991, "Gear Noise," Dudley's Gear Handbook,

D. Townsend, ed., McGraw Hill Book Co., Chapter 14.

Kahraman, A., et al., 1990, "Dynamic Analysis of Geared

Rotors by Finite Elements," NASA TM-102349.

Levine, L.S., and DeFelice, J.J., 1977, "Civil Helicopter

Research Aircraft Internal Noise Prediction," NASA CR-145146.

Lin, H.H., Huston, R.L., and Coy, J.J., 1987a, "On Dynamic

Loads in Parallel Shaft Transmissions. 1: Modelling and Analy-

sis," NASA TM-100180.

Lin, H.H., Huston, R.L., and Cay, J.J., 1987b, "On Dynamic.

Loads in Parallel Shaft Transmissions. 2: Parameter Study,"

NASA TM-100181.

Lin, H.H., Townsend, D.P., and Oswald, F.B., 1989, "Profile

Modification to Minimize Spur Gear Dynamic Loading, " 1989

International Power Transmission and Gearing Conference, 5 th;

Proceedings, ASME, Vol. 1, pp. 455-465 (also, NASA TM-89901).

Oswald, F.B., et al., 1991, "Comparison of Analysis and Experiment for Dynamics of Low Contact Ratio Spur Gears," NASA

TM-103232, Proceedings of the 13th Biennial Conference on Mechanical Vibration and Noise, ASME, Miami, FL, 1991.

Oswald, F.B., et al., 1992, "Comparison of Analysis and Experiment for Gearbox Noise," To be presented at the 1992 International Power Transmission and Gearing Conference, ASME, Phoenix, AZ, 1992. (Also, to be published as NASA TM-105330.)

Pike, J.A., 1981, "Interactive Multiple Spur Gear Mesh

Dynamic Load Program," NASA CR-165514.

Rebbechi, B., et al., 1992, "A Comparison Between Theoretical Prediction and Experimental Measurement of the Dynamic Behavior of Spur Gears," To be presented at the 1992 International Power Transmission and Gearing Conference, Phoenix, AZ, 1992. (Also, to be published as NASA TM-105362.)

Seybert, A.F., et al., 1991, "Acoustical Analysis of Gear Housing Vibration," NASA TM-103691.

Shahan, J.E. and Kamperman, G., 1966, Machine Elements Noise, McGraw Hill Book Co.

Watanabe, Y., and Rouverol, W.S., 1990, "Maximum-Conjugacy Gearing," Gear Design, Manufacturing and Inspection Manual, Society of Automotive Engineers, pp. 57-71. 
Public reporting burden for this collection of information is estimated to average 1 hour per response, including the time for reviewing instructions, searching existing data sources, gathering and maintaining the data needed, and completing and reviewing the collection of information. Send comments regarding this burden estimate or any other aspect of this collection of information, including suggestions for reducing this burden, to Washington Headquarters Services, Directorate for information Operations and Reports, 1215 Jefferson Davis Highway, Suite 1204, Arlington, VA 22202-4302, and to the Office of Management and Budget, Paperwork Reduction Project (0704-0188), Washington, DC 20503.

\begin{tabular}{|l|l|l}
\hline 1. AGENCY USE ONLY (Leave blank) & $\begin{array}{c}\text { 2. REPORT DATE } \\
1992\end{array}$ & $\begin{array}{r}\text { 3. REPORT TYPE AND DATES COVERED } \\
\text { Technical Memorandum }\end{array}$ \\
\hline
\end{tabular}

\section{TITLE AND SUBTITLE}

Effect of Operating Conditions on Gearbox Noise
5. FUNDING NUMBERS

WU 505-63-36

1L162211A47A

6. AUTHOR(S)

Fred B. Oswald, James J. Zakrajsek, Dennis P. Townsend, William Atherton, and Hsiang Hsi Lin

\section{PERFORMING ORGANIZATION NAME(S) AND ADDRESS(ES)}

NASA Lewis Research Center

Cleveland, Ohio 44135-3191

and

Propulsion Directorate

U.S. Army Aviation Systems Command

Cleveland, Ohio 44135-3191

\section{SPONSORING/MONITORING AGENCY NAMES(S) AND ADDRESS(ES)}

National Aeronautics and Space Administration

Washington, D.C. 20546-0001

and

U.S. Army Aviation Systems Command

St. Louis, Mo. 63120-1798
8. PERFORMING ORGANIZATION REPORT NUMBER

E-6732

\section{SUPPLEMENTARY NOTES}

Prepared for the Sixth International Power Transmission and Gearing Conference sponsored by the American Society of Mechanical Engineers, Phoenix, Arizona, September 13-16, 1992. Fred B. Oswald, James J. Zakrajsek, and Dennis P. Townsend, NASA Lewis Research Center; William Atherton, Cleveland State University, Cleveland, Ohio 44115 and Hsiang Hsi Lin, Memphis State University, Memphis, Tennessee 38152 . Responsible person, Fred B. Oswald, (216) 433-3957

12a. DISTRIBUTION/AVAILABILITY STATEMENT 12b. DISTRIBUTION CODE

Unclassified - Unlimited

Subject Category 37

\section{ABSTRACT (Maximum 200 words)}

Low-contact-ratio spur gears were tested in the NASA gear-noise rig to study the noise radiated from the top of the gearbox. The measured sound power from the gearbox top was obtained from a near-field acoustic intensity scan taken at 63 nodes just above the surface. The sound power was measured at a matrix of 45 operating speeds and torque levels. Results are presented in the form of a spectral speed map and as plots of sound power versus torque (at constant speed) and as sound power versus speed (at constant torque). Because of the presence of vibration modes, operating speed was found to have more impact on noise generation than torque level. A NASA gear dynamics code was used to compute the gear tooth dynamic overload at the same 45 operating conditions used for the experiment. Similar trends were found between the analytical results for dynamic tooth overload and experimental results for sound power. Dynamic analysis may be used to design high-quality gears with profile relief optimized for minimum dynamic load and noise.

\section{SUBJECT TERMS}

Gear noise; Spur gears; Acoustic intensity; Sound power OF REPORT

Unclassified
18. SECURITY CLASSIFICATION OF THIS PAGE

Unclassified
19. SECURITY CLASSIFICATION OF ABSTRACT Unclassified 